\title{
Kinerja Pegawai Tata Usaha Pada Masa Pandemi Covid-19
}

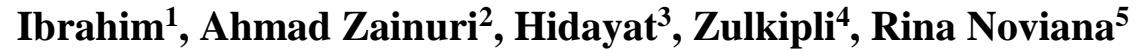 \\ 1,2,3,4,5 Jurusan Manajemen Pendidikan Islam Fakultas Ilmu Tarbiyah dan Keguruan \\ Universitas Islam Negeri Raden Fatah Palembang Sumatera Selatan \\ E-mail: $\underline{\text { ibrahim_uin@ radenfatah.ac.id }}$
}

\section{Info Artikel}

Sejarah Artikel:

Diterima: September 2021

Disetujui: September 2021

Dipublikasikan: September 2021

\section{Kata kunci}

Kinerja; Pegawai Tata

Usaha; Pandemi Covid19

\section{Keywords:}

Performance; Administrative staff; Covid-19 pandemic

\begin{abstract}
ABSTRAK
Penelitian ini bertujuan untuk menganalisis Kinerja Pegawai Tata Usaha Pada Masa Pandemi Covid-19 di SMP Karya Ibu Palembang. Penelitian ini dilaksanakan pada bulan September 2021. Penelitian ini menggunakan jenis penelitian deskriptif kualitatif. Informan pokoknya adalah Kepala Sekolah dan Kepala Tata Usaha. Sumber data primer berupa penelitian lapangan dan data sekunder berupa datadata yang diperoleh dari dokumentasi, buku dan jurnal. Teknik pengumpulan data melalui observasi, wawancara, dan dokumentasi. Teknik analisis data dilakukan dengan pengumpulan data, reduksi data, penyajian data, dan penarikan kesimpulan. Hasil penelitian ini bahwa Kinerja Pegawai Tata Usaha Pada Masa Pandemi Covid19 di SMP Karya Ibu Palembang sudah berjalan baik seperti biasa Kualitas kerja yang dilakukan para pegawai tata usaha sudah baik dimulai dari memahami dahulu apa yang diperintahkan, menyesuaikan jadwal yang telah dibuat dan menyelesaikan tugas dan tanggung jawab secara efektif dan efisien Selanjutnya ketepatan waktu pegawai tata usaha dalam melaksanakan tugas sudah dilakukan dengan dan aktif dalam melakukan pekerjaan pada masa pandemi covid-19 serta sesuai dengan rencana yang telah ditentukan. Kemampuan pegawai tata usaha dalam mengerjakan tugas dan tanggung jawabnya sesuai dengan potensi yang dimiliki. Komunikasi antar pegawai maupun dengan atasan terjalin dengan baik, antara atasan dan bawahan. Kemudian para pegawai memiliki inisiatif dan pemikiran tersendiri untuk mengembangkan ide-ide baru. Serta memiliki sikap disiplin dan bertanggung jawab atas tugas yang diberikan.
\end{abstract}

\begin{abstract}
This study aims to analyze the performance of administrative employees during the Covid-19 pandemic at Karya Ibu Palembang Junior High School. This research was conducted in September 2021. This research uses a qualitative descriptive research type. The main informants are the Principal and the Head of Administration. Primary data sources in the form of field research and secondary data in the form of data obtained from documentation, books and journals. Data collection techniques through observation, interviews, and documentation. Data analysis techniques were carried out by collecting data, reducing data, presenting data, and drawing conclusions. The results of this study show that the performance of administrative employees during the Covid-19 pandemic at Karya Ibu Palembang Middle School has been going well as usual. and responsibilities effectively and efficiently. Furthermore, the punctuality of administrative employees in carrying out their duties has been carried out with and actively in carrying out work during the COVID-19 pandemic and in accordance with the predetermined plan. The ability of administrative employees to carry out their duties and responsibilities in accordance with their potential. Communication between employees and with superiors is well established, between superiors and subordinates. Then the employees have their own initiatives and thoughts to develop new ideas. As well as having a disciplined attitude and being responsible for the assigned tasks.
\end{abstract}




\section{PENDAHULUAN}

Pada saat ini, dunia sedang dilanda wabah yang berbahaya bagi kehidupan manusia. Pada tahun 2019 lalu, berita tentang adanya virus corona telah menyebar keseluruh lapisan masyarakat dunia. Virus yang mematikan ini bisa menyerang keselamatan manusia melalui saluran pernafasan dan organ tubuh lainnya yang dalam keadaan kritis (Cholidah). Covid-19 menimbulkan penyakit mulai dari flu hingga dapat menimbulkan penyakit yang berat seperti Middle East Respiratory Syndrome atau yang disebut dengan MERS-CoV dan penyakit Severe Acute Respiratory Syndrome atau yang disebut dengan SARS-CoV. (Mona, 2020). Pandemi Covid-19 memberikan dampak pada banyak pihak, kondisi ini sudah merambah pada dunia pendidikan, pemerintah pusat sampai pada tingkat daerah memberikan kebijakan untuk meliburkan seluruh lembaga pendidikan. Hal ini dilakukan bertujuan untuk upaya pencegahan meluasnya penularan Covid-19. Diharapakan dengan seluruh lembaga pendidikan tidak melaksanakan aktivitas seperti biasanya, hal ini dapat meminimalisir menyebarnya penyakit Covid-19 ini. Hal serupa juga sudah dilakukan oleh berbagai negara yang terpapar penyakit Covid-19 ini.

Kebijakan lockdown atau karantina dilakukan dengan bertujuan untuk mengurangi interaksi banyak orang yang dapat memberikan akses pada penyebaran virus corona. Kebijakan yang diambil oleh banyak negara termasuk Indonesia dengan meliburkan seluruh aktivitas pendidikan, membuat pemerintah dan lembaga terkait harus menghadirkan alternatif proses pendidikan bagi peserta didik maupun mahasiswa yang tidak bisa melaksanakan proses pendidikan pada lembaga pendidikan. Hal ini didukung oleh Surat Edaran Nomor 4 Tahun 2020 tentang Pelaksanaan Kebijakan Pendidikan Dalam Masa Darurat Penyebaran Coronavirus Disease (Covid-19) ditandatangai oleh Menteri Pendidikan dan Kebudayaan Nadiem Makarim pada tanggal 24 Maret 2020 (Anugrahana, 2020). Penyebaran virus corona telah menjalar keseluruh negeri dimuka bumi, hingga saat ini hanya sebagian kecil Negara saja yang tidak terpapar virus corona. Ketakutan terhadap suatu hal sering disebabkan karena kurangnya pengetahuan dan keilmuan tentang wabah covid-19. Dengan mengetahui seluk beluk covid-19, langkah pencegahan dan penanganan mestinya lebih dipertanggung jawabkan. Organisasi kesehatan dunia menyatakan bahwa penyakit korona covid-19 merupakan pandemi. 
Pandemi Covid-19 merupakan musibah yang memilukan seluruh penduduk bumi. Seluruh segmen kehidupan manusia di bumi terganggu, tanpa kecuali pendidikan. Banyak negera memutuskan menutup sekolah, perguruan tinggi maupun universitas, termasuk Indonesia.

Dalam usaha guna mendukung kelancaran aktivitas pembelajaran di sekolah dibutuhkan suatu unsur yang menunjang aktivitas itu yakni tata usaha sekolah. (Indrawan, 2020) Setiap pekerjaan operatif yang dilaksanakan guna mewujudkan tujuan tertentu pada sebuah organisasi memerlukan adanya kegiatan ketatausahaan. Kegiatan ketatausahaan sudah jadi unsur yang tidak dapat dipisahkan dengan keseluruhan kegiatan organisasi untuk mencapai tujuan, Bahan urusan tata usaha disetiap organisasi sekolah, terutama di SMP/MTs dan SMA/SMK/MA, merupakan pusat kegiatan administrasi pendidikan. Disekolah kantor urusan tata usaha tidak hanya melaksanakan aktivitas pengelolaan surat menyurat, namun menjadi pusat data dan informasi serta mempunyai peranan yang menentukan dalam pengembangan kehidupan sekolah.

Kantor urusan tata usaha dikepalai seorang Kepala Tata Usaha yang bertugas membantu Kepala Sekolah dalam memberikan pelayanan urusan administrasi operatif sekolah serta menyiapkan data dan informasi sekolah dalam rangka pengembangan organisasi sekolah secara keseluruhan. Untuk melaksanakan tugas-tugas tersebut, Kepala Tata Usaha dibantu sejumlah staf yang diberi tugas menangani masing-masing urusan yang menjadi tanggung jawab kantor urusan tata usaha, (Mahmud, 2015). Kinerja merupakan hasil kerja yang telah dicapai oleh pegawai dalam melaksanakan tugas dan tanggungjawab yang dibebankan kepadanya. Hasil kerja tersebut dapat diperoleh dengan baik tidak terlepas dari adanya dukungan lingkungan kerja dan bimbingan dan arahan pimpinan organisasi. Menurut Sinambela (dalam Budi Yulianto) mendifinisikan kinerja sebagai kemampuan pegawai dalam melakukan keahlian tertentu untuk mengetahui seberapa jauh kemampuannya dalam melaksanakan tugas yang dibebankan kepadanya dengan kriteria yang jelas dan terukur. (Yulianto, 2020)

Menurut Payman J. Simanjuntak (dalam Ahmad Susanto) kinerja adalah tingkat pencapaian hasil atas pelaksanaan tugas tertentu dalam rangka pencapaian tujuan organisasi. Dalam hal ini, Simanjuntak menegaskan bahwa kinerja adalah sesuatu yang penting dalam rangka pencapaian tujuan organisasi, karena setiap individu atau organisasi tentu saja memiliki tujuan yang akan dicapai dengan menetapkan target atau sasaran. Keberhasilan individu atau organisasi dalam mencapai target atau sasaran tersebut itulah merupakan kinerja. Kinerja pada dasarnya dapat dilihat dari dua segi yaitu kinerja pegawai (individu) dan kinerja organisasi. Kinerja pegawai adalah unjuk kerja perorangan dalam suatu organisasi, sedangkan kinerja organisasi adalah totalitas hasil kerja yang dicapai suatu organisasi. Kinerja pegawai dan 
kinerja organisasi memiliki keterkaitan sangat erat. Jadi, kinerja seorang pegawai/karyawan adalah hasil atau keluaran (outcomes) dari sebuah pekerjaan yang ditugaskan dalam suatu organisasi/institusi.

Istilah tata usaha sering disebut sebagai pekerjaan perkantoran (office work). Menurut George Terry pekerjaan perkantoran meliputi penyampaian keterangan secara lisan dan pembuatan warkat-warkat tertulis dan laporan-laporan sebagai cara untuk meningkatkan banyak hal dengan cepat guna menyediakan suatu landasan fakta bagi tindakan kontrol dari pimpinan. Tata usaha sekolah merupakan ujung tombak pelayanan jasa pendidikan suatu lembaga, yaitu sebagai badan administrasi sekolah yang secara langsung menangani pelayanan didalam internal maupun eksternal sekolah yang mempunyai tugas dan fungsi melayani pelaksanaan pekerjaan-pekerjaan operatif untuk mencapai tujuan dari suatu organisasi, menyediakan keterangan-keterangan bagi pucuk pimpinan organisasi untuk membuat keputusan atau melakukan tindakan yang tepat, dan membantu kelancaran perkembangan organisasi sebagai suatu keseluruhan. Maka, melalui manajemen tata usaha yang baik, juga akan mempengaruhi kualitas pelayanan suatu lembaga. (Amiruddin, 2017). Sedangkan pengertian tata usaha menurut pedoman pelayanan tata usaha untuk perguruan tinggi adalah : Tata Usaha adalah segenap kegiatan mengelolah surat menyurat dari ke enam bahan keterangan semua diperlukan oleh pemimpin organisasi untuk menopang proses pengambilan keputusan. Jadi, dapat disimpulkan bahwa tata usaha sekolah adalah suatu kegiatan administrasi pendidikan yang melayani layanan secara internal dan eksternal untuk mencapai suatu tujuan.

Virus corona adalah virus yang biasanya menyerang saluran pernapasan. Nama ini berasal dari kata latin "corona", yang artinya adalah mahkota. Nama ini diambil karena bagian luar yang mengelilingi virus-virus ini runcing seperti mahkota. Ada banyak varian virus sejenis ini, namun hanya tujuh yang diketahui menginfeksi manusia seperti covid-19, SARS, dan MERS, SARS diyakini telah berkembang di Cina dari kelelawar hingga musang dan menginfeksi manusia. MERS telah menyebar dari kelelawar ke unta, kemudian ke manusia di area Timur Tengah. Belum ada yang tahu dari mana covid-19 berasal. Corona virus merupakan keluarga besar virus yang menyebabkan penyakit pada manusia dan hewan. Pada manusia biasanya menyebabkan penyakit infeksi saluran pernapasan, mulai flu biasa hingga penyakit yang serius seperti Middle East Respiratory Syndrome (MERS) dan sindrom pernapasan akut berat/ Severe Acute Respiratory Syndrome (SARS), penyakit ini menular melalui droplet dari batuk dan bersin. Virus ini dapat tetap bertahan hingga tiga hari atau dalam aerosol selama tiga jam. Virus ini juga telah ditemukan difeses, tetapi hingga maret 2020 tidak diketahui apakah penularan melalui feses juga. (Ais, 2020). 
Coronavirus adalah virus RNA dengan ukuran partikel 120-160mm. Virus ini meninfeksi terutama hewan, termasuk diantaranya adalah kelelawar dan unta. Virus corona adalah sekelompok virus yang menyebabkan penyakit kepada manusia maupun hewan. Salah satu dampak yang ditimbulkan oleh virus corona adalah gangguan saluran pernafasan, mulai dari filek hingga batuk yang parah. Ketika penderita penyakit covid-19 batuk atau bersin, melalui tetesan air liur, maka virus tersebut dapat menyebar dengan cepat. Gejala yang timbul ketika seseorang terkena penyakit covid-19 adalah batuk, demam, sesak nafas. Bagi penderita masa inkuibasi adalah sekitar 5 sampai 6 hari atau paling lama 14 hari.

\section{METODE PENELITIAN}

Jenis penelitian yang digunakan dalam penelitian ini adalah jenis penelitian kualitatif. Adapun pendekatan penelitian adalah dengan pendekatan studi kasus. Jenis data dalam penelitian ini adalah data kualitatif. Adapun yang menjadi sumber data dalam informan ini yaitu: Informan pokoknya adalah Kepala Sekolah dan Kepala Tata Usaha. Sumber data primer berupa penelitian lapangan dan data sekunder berupa data-data yang diperoleh dari dokumentasi, buku dan jurnal. Teknik pengumpulan data dalam penelitian ini teknik pengumpulan data yang dilakukan adalah wawancara, observasi, dan dokumentasi. Teknik analisa data, Reduksi Data (Data Reduction), Penyajian data (Data Display), Verifikasi/Penarikan kesimpulan.

\section{HASIL PENELITIAN}

1. Kualitas kerja Tata Usaha

Kualitas kerja pegawai tata usaha pada masa pandemi sudah baik dan berjalan sesuai dengan prosedur covid-19 dan juga pegawai tata dalam kinerjanya pada masa pandemi ini tetap aktif seperti biasa, namun dalam menyelesaikan tugas yang diberikan ada beberapa yang harus ditingkatkan lagi seperti penyusunan berkas-berkas yang masih kurang rapi dan kedisiplinan pegawai, dalam pelaksanaan tugasnya dibuatkan jadwal dan tetap mematuhi protokol Kesehatan dengan menjaga jarak, memakai masker dan mencuci tangan, para pegawai yang datang ke sekolah secara bergantian, selain itu pelayanan administrasi sudah sesuai dengan kebutuhan siswa dan bersedia membantu keperluan yang dibutuhkan oleh kepala sekolah dan guru.

2. Ketepatan waktu kinerja tata usaha 
Pelaksanaan tugas pegawai tata usaha dalam melakukan pekerjaan secara tepat waktu para pegawai mampu menyelesaikan pekerjaan sesuai dengan rencana, ketentuan yang ditetapkan mulai dari pengumpulan data kesiswaan yang akan dimasukkan ke dalam buku induk, ataupun untuk urusan mutasi siswa, selain itu meskipun dalam keadaan masa pandemi para pegawai selalu aktif dalam menyelesaikan pekerjaannya agar mencapai tujuan yang ingin dicapai.

3. Kemampuan dalam bekerja

Para pegawai tata usaha mengerjakan tugas dan tanggung jawabnya sesuai dengan potensi dan sudah memiliki pengetahuan tentang administrasi, meski sudah memiliki pengetahuan tentang administrasi tetapi pegawai tata usaha belum mengetahui secara mendalam hal ini dipengaruhi oleh tingkat pendidikan dan pengalaman yang mereka miliki. tetapi kemampuan atau skill mereka dalam mengerjakan pekerjaan sesuai dengan apa yang telah direncanakan dan pastinya selalu mematuhi protokol kesehatan. Selaku pegawai tata usaha selalu ingin memberikan yang terbaik untuk kemajuan sekolah. kemampuan kinerja pegawai tata usaha pada masa covid-19 di SMP Karya Ibu Palembang sudah baik karena para pegawai selalu ingin memberikan yang terbaik untuk sekolah dan memiliki pengalaman serta tingkat pendidikan yang sesuai dengan bidang keahliannya sehingga dapat berdampak pada kemampuan dalam bekerja di Lembaga Pendidikan/sekolah.

4. Komunikasi dan interaksi pegawai tata usaha

Komunikasi dan interaksi antara atasan dan pegawai itu terjalin dengan baik begitupun dengan komunikasi mereka sesama para pegawai, mereka selalu berkomunikasi untuk setiap pekerjaan yang mereka lakukan baik secara langsung maupun melalui via handphone, Komunikasi dan interaksi yang dilakukan oleh para pegawai selalu terjalin dengan baik, saling bertukar ide dan saling membantu. Dalam menyampaikan informasi antar pegawai maupun atasan mereka menggunakan via whatsapp bisa dengan whatsapp pribadi maupun grup. Dengan adanya komunikasi yang baik maka akan menciptakan kinerja yang baik, komunikasi yang dilakukan bukan hanya dengan para pegawai tata usaha saja, tetapi dengan atasan dan para dewan guru karena komunikasi yang baik akan menjadikan suatu tugas yang dikerjakan akan terasa lebih mudah, komunikasi dilakukan agar tidak terjadi kesalahpahaman antar satu sama lain.

5. Inisiatif pegawai dalam bekerja

Para pegawai memiliki dan dapat mengembangkan ide-ide baru dalam melaksanakan tugas memiliki inisiatif, bisa dilihat dari kinerja pegawai apabila diberikan tugas segera untuk mengerjakannya, selain itu berani mengambil keputusan. Karena dengan adanya inisiatif 
dalam menjalankan tugas kita perlu mengadakan evaluasi tindakan perbaikan dari kepala sekolah dan kepala tata usaha. Apalagi pada masa pandemi ini kita dituntu untuk dapat mengembangkan ide-ide dalam hal ini kami membuat website untuk penerimaan peserta didik baru, penyimpanan data secara online google drive.

6. Disiplin dan bertanggung jawab

Para pegawai memiliki sikap disiplin dan bertanggung jawab atas tugas yang diberikan dan juga para pegawai memiliki sikap dan perilaku yang baik dalam melakukan pelayanan dan dalam melakukan pelayanan para pegawai selalu mematuhi protokol kesehatan tetapi masih ada beberapa pegawai yang sering datang terlambat. Pada kedisiplinan absensi pegawai mengisi absen sesuai dengan jam kerja ketika mereka datang ke sekolah, dan untuk tanggung jawab telah diberikan oleh kepala sekolah sesuai dengan tugas dan fungsinya masing-masing, para pegawai harus melaksanakan tanggung jawab tersebut. Meskipun dalam kondisi pandemi akan tetapi tingkat kedisiplinan dan tanggung jawab pegawai tata usaha SMP karya Ibu cukup baik, seperti kerapian dalam penyusunan berkas-berkas di sekolah

\section{PEMBAHASAN}

1. Kualitas kinerja

Kualitas kerja adalah kualitas kerja yang dicapai berdasarkan syarat-syarat kesesuaian dan kemampuannya yang tinggi pada gilirannya akan melahirkan penghargaan dan kemajuan serta perkembangan organisasi melalui peningkatan pengetahuan dan keterampilan secara sistematis sesuai tuntutan ilmu pengetahuan dan teknologi yang semakin berkembang pesat (Debby D.Y. Lintjewas, Vol. 2, 2016)

Menurut Payman J. Simanjuntak kinerja adalah tingkat pencapaian hasil atas pelaksanaan tugas tertentu dalam rangka pencapaian tujuan organisasi. Dalam hal ini, Simanjuntak menegaskan bahwa kinerja adalah sesuatu yang penting dalam rangka pencapaian tujuan organisasi, karena setiap individu atau organisasi tentu saja memiliki tujuan yang akan dicapai dengan menetapkan target atau sasaran. Keberhasilan individu atau organisasi dalam mencapai target atau sasaran tersebut itulah merupakan kinerja. (Susanto, 2016)

Kinerja pada dasarnya dapat dilihat dari dua segi yaitu kinerja pegawai (individu) dan kinerja organisasi. Kinerja pegawai adalah unjuk kerja perorangan dalam suatu organisasi, sedangkan kinerja organisasi adalah totalitas hasil kerja yang dicapai suatu organisasi. Kinerja pegawai dan kinerja organisasi memiliki keterkaitan sangat erat. Jadi, kinerja 
seorang pegawai/karyawan adalah hasil atau keluaran (outcomes) dari sebuah pekerjaan yang ditugaskan dalam suatu organisasi/institusi. (Fattah, 2017)

Kualitas kerja pegawai tata usaha sesuai dengan pengerjaan tugas dan para pegawai selalu aktif dalam melakukan pelayanan administrasi. sesuai dengan kebutuhan siswa dan bersedia membantu keperluan yang dibutuhkan oleh kepala sekolah dan guru.

2. Ketepatan waktu

Ketepatan waktu (timeliness) merupakan sebuah informasi bagi pembuat keputusan pada saat dibutuhkan dan sebelum informasi tersebut telah kehilangan kemampuannya untuk mempengaruhi sebuah keputusan (Ramadhaniyanti, 2016).

Ketepatan waktu yaitu berkaitan dengan sesuai atau tidaknya waktu penyelesaian pekerjaan dengan target waktu yang direncanakan. Setiap pekerjaan diusahakan untuk selesai sesuai dengan rencana agar tidak mengganggu pada pekerjaan yang lain. (Debby D.Y. Lintjewas, Vol. 2, 2016)

Ketepatan waktu kinerja pegawai tata usaha pada masa covid-19 di SMP Karya Ibu Palembang sudah dilakukan cukup baik, sesuai dengan tuntutan yang diperintahkan. Dalam pembuatan surat para pegawai bisa menyesaikannya dalam waktu yang begitu singkat, dilihat dari banyak atau sedikitnya surat yang dibuat.

3. Kemampuan

Kemampuan kerja/prestasi kerja adalah suatu hasil kerja yang dicapai seseorang dalam melaksanakan tugas-tugas yang dibebankan kepadanya yang didasarkan atas kecakapan, pengalaman dan kesungguhan serta waktu.

Kemampuan yang dilakukan oleh pegawai sudah baik sesuai dengan teori yang dikemukakan oleh Hasibuan bahwa para pegawai melaksanakan tugas-tugas yang dibebankan kepadanya yang didasarkan atas kemampuan yang mereka miliki.

4. Komunikasi

Menurut Wahlstrom komunikasi adalah proses dimana terjadi pemberian informasi, gagasan, dan perasaan yang tidak saja dilakukan secara lisan dan tertulis melainkan melalui bahasa tubuh, atau gaya atau tampilan pribadi, atau hal lain disekelilingnya yang memperjelas sebuah makna (Dyatmika, 2020). Komunikasi sebagai suatu proses pertukaran ide, pesan dan kontak serta interaksi sosial termasuk aktivitas pokok dalam kehidupan manusia (Nofrion, 2016).

Komunikasi diantara para pegawai, baik kepala sekolah, sesama pegawai dan dengan siswa sudah terjalin dengan baik dan saling melengkapi satu sama lain baik secara langsung maupun secara tidak langsung yang berkomunikasi lewat whatsapp 
5. Inisiatif

Menurut Suryana mengatakan bahwa inisiatif adalah kemampuan mengembangkan ide dan dalam memecahkan masalah, dan menemukan peluang (thinking new things) (Latief \& Utud, 2017). para pegawai dapat mengembangkan ide-ide baru sesuai dengan potensi yang mereka miliki dan selalu melakukan evaluasi kepada kepala sekolah dan kepala tata usaha apabila ada kesalahan.

6. Disiplin dan bertanggung jawab

Disiplin kerja menurut pendapat Alex S. Nitisemito kedisiplinan adalah suatu sikap tingkah laku dan perbuatan yang sesuai dengan peraturan dari perusahaan baik secara tertulis maupun tidak tertulis (Sumanto, 2020). Burhanuddin menyatakan bahwa tanggung jawab adalah kesanggupan untuk menetapkan sikap terhadap suatu perbuatan yang diemban dan kesanggupan untuk memikul resiko dari sesuatu perbuatan yang dilakukan (Nurhadi \& Irhamuddin Harahap, 2020).

Kedisiplinan dan tanggung jawab diberikan kepada para pegawai dalam melakukan pelayanan yang sesuai dengan kebutuhan sehingga kepala sekolah merasa puas dengan hasil kerja yang dilakukan oleh pegawai.

\section{SIMPULAN}

Hasil penelitian tentang kinerja pegawai tata usaha pada masa pandemi covid-19 di SMP karya Ibu Palembang sudah berjalan baik seperti biasa dilakukan dimulai dari Kinerja Pegawai Tata Usaha Pada Masa Pandemi Covid-19 di SMP Karya Ibu Palembang sudah berjalan baik seperti biasa Kualitas kerja yang dilakukan para pegawai tata usaha sudah cukup baik dengan menyelesaikan tugas dan tanggung jawab secara efektif dan efisien Selanjutnya ketepatan waktu pegawai tata usaha dalam melaksanakan tugas sudah dilakukan dengan cukup baik dalam melakukan pekerjaan pada masa pandemi covid-19 serta sesuai dengan rencana yang telah ditentukan. Kemampuan pegawai tata usaha dalam mengerjakan tugas dan tanggung jawabnya sesuai dengan potensi yang dimiliki. Komunikasi antar pegawai maupun dengan atasan terjalin dengan baik, antara atasan dan bawahan. Kemudian para pegawai memiliki inisiatif dan pemikiran tersendiri untuk mengembangkan ide-ide baru. Serta memiliki sikap disiplin dan bertanggung jawab atas tugas yang diberikan. 


\section{REFERENSI}

Ais, R. (2020). Komunikasi Efektif di Masa Pandemi Covid-19. Banten: Makmood.

Amiruddin. (2017). Kependidikan Islam, 127.

Anugrahana, A. (2020). Pembelajaran Daring Selama Masa Pandemi Covid-19. Pendidikan dan Kebudayaan, 282.

Asriel, A. S. (2016). Manajemen Kantor. Jakarta: Kencana.

Cholidah, L. I. (n.d.). Berdaya Membangun Negeri di Masa Covid-19. Bandung: UIN Sunan Gunung Djati.

Debby D.Y. Lintjewas. (Vol. 2, 2016). Kualitas Kerja Pegawai. Jurnal Ilmu Sosial \& Pengelolaan Sumberdaya Pembangunan, 49.

Dyatmika, T. (2020). Ilmu Komunikasi. Yogyakarta: Zahir Publishing.

Fattah, H. (2017). Kepuasan Kerja \& Kinerja Pegawai. Yogyakarta: Elmatera.

Indrawan, I. (2020). Manajemen Personalia dan Kearsipan Sekolah. Jateng: Lakeisha.

Latief, R., \& Utud, Y. (2017). Menjadi Produser Televisi. Jakarta: Kencana.

Mahmud, H. (2015). Administrasi Pendidikan. Makassar: Aksara Timur.

Mona, N. (2020). Konsep Isolasi Dalam Jaringan Sosial Untuk Meminalisasi Efek Contagious. Sosial Humaniora, 117.

Nofrion. (2016). Komunikasi Pendidikan. Jakarta: Kencana.

Nurhadi, \& Irhamuddin Harahap. (2020). Konsep Tanggung Jawab Pendidik Dalam Islam. Pekanbaru: Guepedia.

Ramadhaniyanti, A. (2016). Faktor-faktor yang Mempengaruhi Ketepatan Waktu Penyampaian Laporan Keuangan. Sekolah Tinggi Ilmu Ekonomi Perbanas, 4.

Rumpa, B. \&. (2020). Jangan Takut Virus Corona. Yogyakarta: Rapha.

Sumanto. ( 2020). Sumber Daya Manusia. Yogyakarta: CV: Andi Offset.

Susanto, A. (2016). Manajemen Peningkatan Kinerja Guru. Jakarta: Prenamedia Group.

Yulianto, B. (2020). Perilaku Penggunaan APD Sebagai Alternatif Meningkatkan Kinerja Karyawan yang Terpapar Bising Intensitas Tinggi. Surabaya: Scopindo Media. 